\title{
ANALISIS KETERCAPAIAN SIKAP DI SMP MATHLA'UL ANWAR MARGAHAYU
}

\section{ATTITUDE ACHIEVEMENT ANALYSIS IN SMP MATHLA'UL ANWAR MARGAHAYU}

\section{Icmiati Santika}

Universitas Islam Negeri Sunan Gunung Djati Bandung, Indonesia Email: icmiati91@gmail.com

Chaerul Rohman

Universitas Islam Negeri Sunan Gunung Djati Bandung, Indonesia Email: chaerulrochman99@uinsgd.ac.id

\section{Dindin Jamaluddin}

Universitas Islam Negeri Sunan Gunung Djati Bandung, Indonesia Email: din2jamaluddin@uinsgd.ac.id

\begin{abstract}
Abstrak
Penelitian ini dilakukan untuk mengukur pencapaian penghargaan terhadap orang tua, kerendahan hati, hemat dan hidup sederhana. Pentingnya membahas masalah ini karena merupakan salah satu kompetensi yang harus diraih oleh peserta didik SMP. Metode penelitian ini menggunakan metode deskriptif kuantitatif, dengan jumlah partisipasi 23 orang dari 8 siswa kelas D SMP Mathla'ul Anwar Margahayu Kabupaten Bandung. Instrumen yang digunakan dalam penelitian ini berupa lembar angket dengan 10 indikator untuk mengukur sikap siswa. Kesimpulan dari penelitian ini adalah (1) sikap siswa secara keseluruhan menunjukkan hasil yang beragam dengan rata-rata pencapaian $61 \%$. (2) Indikator yang belum mencapai nilai maksimal adalah sikap rendah hati, hemat, dan sederhana. Rekomendasi dari penelitian ini adalah perlunya perhatian khusus dari orang tua untuk menanamkan karakter tersebut melalui pola asuh yang tepat pada remaja.
\end{abstract}

Kata Kunci: sikap, pengasuhan

\begin{abstract}
This research was conducted to measure the attainment of respect for parents, humility, frugality and simple life. It is important to discuss recall is one of the competencies that must be achieved by the participant students in junior high school. This research method uses descriptive quantitative methods, with the amount of participation of 23 people from 8 class D junior Mathla'ul Anwar Margahayu Bandung regency. The instrument used in this study is a questionnaire sheet with 10 indicators to measure the attitudes of students. The conclusions of this study are (1) the overall attitude of the students shows a variety of results with an average achievement of $61 \%$. (2) indicators that have not reached the maximum score are humble, frugal and simple living attitudes. The recommendation of this research is the need for special attention from parents to instill this character through proper parenting for teenagers.
\end{abstract}

Keywords: attitude, parenting 


\section{A. Pendahuluan}

Pendidikan Agama Islam (PAI) sebagai salah satu mata pelajaran di sekolah yang bertujuan untuk menanamkan iman dan takwa dengan pemberian pengetahuan, penghayatan, dan pengamalan. Sejalan dengan itu tujuan pendidikan nasional yang dituangkan dalam UUSPN No. 20 Tahun 2003 bab II pasal 3 menyatakan bahwa: "pendidikan bertujuan untuk mengembangkan potensi dalam diri peserta didik menjadi manusia beriman dan takwa, berakhlak mulia, sehat, berilmu, cakap, kreatif, mandiri, warganegara yang demokratis bertanggung jawab. ${ }^{1}$ Komponen pembelajaran merupakan komponen-komponen penting yang harus ada dalam pembelajaran komponen tersebut, di antaranya adalah tujuan, bahan pelajaran, siswa, guru, metode, situasi dan kondisi serta evaluasi atau penilaian. ${ }^{2}$

Evaluasi PAI di sekolah memiliki 3 aspek penilaian yaitu pengetahuan, keterampilan dan sikap. Pengetahuan sebagai dasar keilmuan dalam mempraktekan ajaran agama Islam. Tetapi pada praktiknya ada hal yang kurang terperhatikan dalam mengevaluasi PAI yaitu aspek sikap. Pembelajaran PAI di sekolah lebih condong dengan pemberian pengetahuan untuk mengasah kognitif peserta didik, dan kurang memperhatikan aspek moral.

Dalam kurikulum 2013 terdapat dua cabang sikap yang ditekankan, yaitu sikap spiritual dan sikap sosial. Sikap spiritual merupakan perwujudan taat seorang hamba kepada Tuhan yang berdampak pada sikap yang sesuai dengan yang diperintahkan oleh Tuhan. Sedangkan sikap sosial merupakan gambaran hubungan antar manusia dengan lingkungan aspek ini menekankan pentingnya hubungan sosial. ${ }^{3}$ Sebagaimana tujuan pendidikan agama Islam bahwa sifat takwa merupakan cerminan sikap seorang muslim. Sikap yang baik sesuai dengan ajaran agama merupakan tujuan utama dari pendidikan agama Islam. Sikap seorang anak sangat dipengaruhi oleh lingkungan, yang salah satunya adalah lingkungan keluarga.

Keluarga sebagai lingkungan terkecil memiliki pola asuh yang berbeda-beda. Menurut Baumrind, pola asuh merupakan cara atau metode yang dikukan orangtua

\footnotetext{
${ }^{1}$ Departemen Pendidikan Nasional, Undang-Undang Nomor 20 Tahun 2003 Tentang Sistem Pendidikan Nasional (Jakarta: Depdiknas, 2003).

${ }^{2}$ Acep Komarudin Jamaludin \& Koko Khoerudin, Pembelajaran Perspektif Islam (Bandung: Remaja Rosdakarya, 2015), 70

${ }^{3}$ Fatimah \& Rusli Malli, "Implementasi Kurikulum 2013 terhadap Sikap Peserta Didik dalam Pembelajaran Pendidikan Agama Islam," TARBAWI: JURNAL PENDIDIKAN AGAMA ISLAM, Vol. 2, No. 1 (2017): 91-99.
} 
dalam membesarkan anak dengan memenuhi kebutuhan, memberikan perlindungan, mendidik, serta mempengaruhinya dalam kehidupan sehari-hari. ${ }^{4}$ Pola asuh ini dilatarbelakangi oleh kehidupan orangtua sehingga berdampak pada berbeda-bedanya tingkah laku anak. Hal tersebut terjadi ketika seorang anak memperhatikan cara orangtua memperlakukan mereka kemudian diresapi dan menudian menjadi kebiasaan terhadap anak tersebut. ${ }^{5}$ Terdapat beberapa model pola asuh orangtua, di antaranya:

1. Pola asuh demokrasi

Pola asuh demokrasi adalah pola asuh yang mengedepankan kepentingan anak, tetapi dengan aturan-aturan untuk mengendalikan anak. Orangtua yang menerapkan pola asuh demokrasi akan menunjukkan sikap rasional, realistis, orangtua juga memberikan kebebasan kepada anak untuk memiliki dan menentuan tidakan yang mereka lakukan, serta orangtua selalu bersikap hangat. ${ }^{6}$

2. Pola asuh otoriter

Pola asuh otoriter gaya pengasuhan orangtua yang membatasi dengan memberikan banyak aturan untuk diikuti oleh anak dan adanya hukuman apabila tidak sesuai dengan yang orangtua inginkan yang bertujuan untuk menamkan sifat menghormati pekerjaan dan usaha orangtua. Orangtua yang mempunyai sikap otoriter biasanya bersikap: a) bersikap sepihak dalam menentukan apa yang harus anak perbuat; b) bila salah anak tidak diberi kesempatan untuk memberikan alasan dan penjelasan; c) bila adanya hukuman maka hal tersebut berbentuk fisik; dan d) orangtua tidak pernah memberikan reward, baik berupa kata-kata ataupun bentuk lain. ${ }^{7}$

\section{Pola asuh permisif}

Pola asuh permisif merupakan pola asuh yang membiarkan atau membebaskan anak untuk melakukan segala sesuatu. Orangtua selalu membolehkan apapun yang anak lakukan. Sehingga kurangnya reward dan punishment terhadap anak yang menyebabkan orangtua tidak enak ketika memberikan hukuman. ${ }^{8}$

\footnotetext{
${ }^{4}$ Yuli A. Rozali, "Kecerdasan Interpersonal Remaja Ditinjau dari Penerapan Pola Asuh Orangtua. In Seminar Psikologi \& Kemanusiaan (pp. 446-452).

${ }^{5}$ Hikma Dirgantara, "4 Jenis Pola Asuh untuk Mendidik Anak," https://www.finansialku.com, Diakses 29 Mei 2019.

${ }^{6}$ S. Rahayu \& F. Hendrati, "Pola Asuh Demokratis dan Kecerdasan Emosional dengan Prestasi Belajar Siswa-Siswi SMP Bilingual,” Persona: Jurnal Psikologi Indonesia, Vol. 4, No. 3 (2015).

${ }^{7}$ E. I. E. Putri \& I. G. A. A. Noviekayati, "Religiusitas, Pola Asuh Otoriter dan Perilaku Prososial Remaja di Pondok Pesantren," Persona: Jurnal Psikologi Indonesia, Vol. 4, No. 3 (2015).

${ }^{8}$ Hikma Dirgantara, "4 Jenis Pola Asuh..."
} 


\section{Pengabaian}

Pola asuh ini biasanya digunakan oleh orangtua yang mengejar karir yang tidak memiliki waktu untuk keluarga dan anak. Dampak dari anak yang mendapatkan pola asuh pengabaian cenderung tertutup, rendah diri, tidak percaya diri hingga depresi. ${ }^{9}$

Menurut Zakiah Darajat menyatakan bahwa dalam mendidik anak orangtua disarankan untuk menggunakan pola asuh permisif yaitu tidak terlalu membebaskan, tidak terlalu menekan, memberikan larangan keras,tidak menekankan sesuaitu sesuai keinginan orangtua. Pendidikan yang dilakukan dengan kekerasan pada anak akan berdampak buruk bagi anak. Serta, pendidikan yang terlalu membebaskan anak akan menjadi pengaruh yang buruk bagi pertumbuhan anak. Maka pendidikan yang tepat menurut Zakiah Darajat adalah dengan pola pendidikan demokratis. ${ }^{10}$

Penerapan pola asuh yang berbeda-beda akan berdampak pada sikap anak, baik berhadapan dengan keluarga atau dengan oranglain. Selain faktor pola asuh orangtua terdapat bebapa faktor yang dapat mempengaruhi sikap peserta didik seperti lingkungan dan pembelajaran di kelas.

Fakta yang terjadi di sekolah SMP MA Margahayu berdasarkan hasil observasi yang yang dilakukan oleh peneliti ditemukan karakter siswa yang ditujukan adalah bersikap sopan santun terhadap guru, penurut taat aturan, taat beribadah. Tetapi bagaimanakan karakter perta didik tunjukan ketika dirumah mengingat setiap orangtua memiliki pola asuh yang berbeda-beda dalam mendidik anak.

\section{B. Metode Penelitian}

Metode penelitian ini menggunakan penelitian kuantitatif deskriptif. penelitian kualitatif ini digunakan untuk mendeskripsikan fenomena yang ada dalam lingkungan remaja yang dikuatkan oleh penelitian-penelitian yang berhubungan dengan kajian pada penelitian ini. Partisipan dalam penelitian ini adalah siswa kelas 8 D SMP Mathla'ul anwar yang memiliki usia antara 14-15 tahun (remaja).

Instrumen yang digunakan adalah soal tes sebanyak 10 soal tentang aspek sikap di kelas 8 merujuk pada kompetensi dasar dan kompetensi inti pada silabus kelas 8 . Hal ini dilakukan untuk mendapatkan jawaban autentik. Yang hasilnya dikomparasikan

\footnotetext{
${ }^{9}$ Ibid.

${ }^{10}$ Firda Pratiwi, et. al., "Pendidikan Anak Menurut Zakiah Darajat," POTENSIA: Jurnal Kependidikan Islam, Vol. 4, No. 1 (2018): 46-62.
} 
dengan jurnal-jurnal berhubungan. Observasi digunakan sebagai alat perbandingan antara jawaban yang dibuat dengan realitas yang terjadi di lapangan.

Kompetensi dasar pada tes ini adalah menghargai perilaku hormat dan patuh kepada orangtua dan guru sebagai implementasi dari pemahaman Q.S. Al-Nisa: 36 dan hadits terkait. Menghargai perilaku rendah hati, hemat, dan hidup sederhana sebagai implementasi dari pemahaman Q.S. Al-Furqan : 63, al-Isra: 27 dan hadits terkait.

Data yang diperoleh berupa skor aspek sikap dengan ketentuan tiap soal:

\begin{tabular}{clc}
\hline No. & \multicolumn{1}{c}{ Ketercapaian indikator } & Skor \\
\hline 1. & Menjawab lebih dari 4 & 4 \\
2. & Menjawab 3 jawaban & 3 \\
3. & Menjawab 2 jawaban & 2 \\
4 & Menjawab 1 jawaban & 1 \\
5. & Tidak menjawab & 0 \\
\hline
\end{tabular}

Dengan nemikian, dapat diperoleh jumlah skor maksimal berjumlah 40. Dan dipersentasekan setiap butir soalnya dengan menggunakan rumus:

prosentasi ketercapaian $=\frac{\text { perolehan skor }}{\text { skor maksimum }} \times 100$

Adapun untuk menentukan kualifikasi persentase menggunakan ketentuan ${ }^{11}$ :

\begin{tabular}{cc}
\hline Tingkat Penguasaan & Predikat \\
\hline $80-100 \%$ & Sangat Baik \\
$70-79 \%$ & Baik \\
$60-69 \%$ & Cukup \\
$50-59 \%$ & Kurang \\
$0-49 \%$ & Gagal \\
\hline
\end{tabular}

Setelah diperoleh hasil analisis data, maka dilanjutkan dengan triangulasi antara hasil sebaran angket dengan realita hasil observasi guru dilapangan mengenai fenomena-fenomena yang berhubungan dengan penelitian.

\section{Hasil dan Pembahasan}

Berdasarkan hasil pengambilan data dan analisis data tentang konsep patuh terhadap orangtua hubungannya dengan rasa takut anak di SMP Mathla'ul Anwar Margahayu Kabupaten Bandung, maka dapat dijelaskan sebagai berikut:

\footnotetext{
${ }^{11}$ Muhibbin Syah, Psikologi Pendidikan dengan Pendekatan Baru (Bandung: Remaja Rosdakarya, 2013), 151.
} 
Icmiati Santika, Chaerul Rohman, Dindin Jamaluddin: Analisis Ketercapaian Sikap di SMP Mathla'ul Anwar Margahayu

1. Profil Pencapaian Aspek Sosial di SMP Mathla'ul Anwar

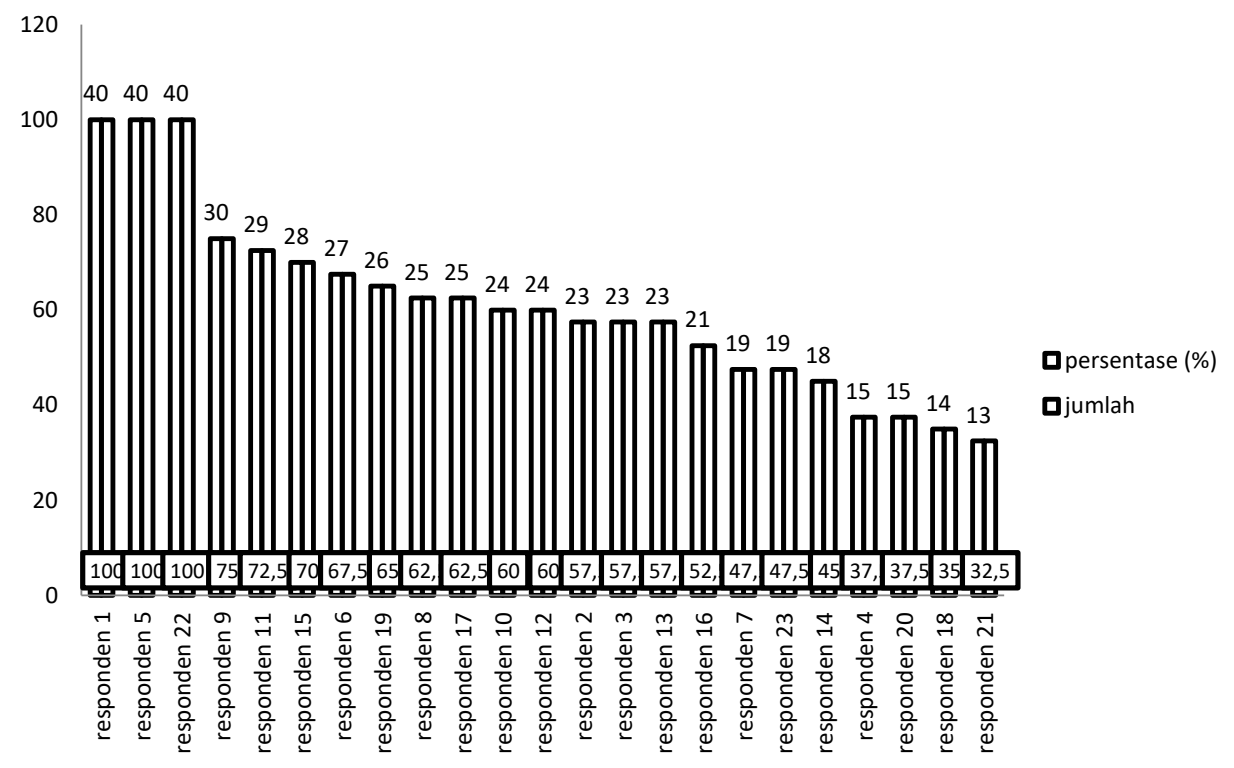

Gambar 1. Persentase Tiap Responden di SMP Mathla'ul Anwar

Gambar 1 menunjukkan persentase pencapaian setiap siswa di SMP Mathla'ul Anwar Margahayu, dari 23 responden dapat dikelompokkan menjadi 3, yaitu: kelompok tinggi, kelompok rendah, dan kelompok sedang. Kelompok tinggi terdapat 6 responden dengan jumlah persentase antara 100\% - 70\%. Kelompok rendah terdapat 10 responden dengan jumlah persentase antara 50\% - 69\%. Kelompok rendah terdapat 7 responden dengan jumlah persentase antara 0\%-49\%. Kelompok tinggi di antaranya responden nomor 1, nomor 5 nomor 22 dengan jumlah persentase $100 \%$, kelompok terendah di antaranya responden 21 persentase 32,5\%, responden 18 jumlah persentase $35 \%$, responden 20 dan 4 jumlah persentase 37, 5\%. Maka dapat disimpulkan bahwa persentase tertinggi didapatkan oleh 3 responden, yaitu nomor 1, 5, dan 22 menunjukkan persentase $100 \%$ dengan rata-rata 4. Responden nomor 9 menunjukkan persentase $75 \%$ dengan rata-rata 3 . Responden 11 menunjukkan persentase $72,5 \%$ dengan rata-rata 2,9. Responden yang mendapatkan persentase terendah didapatkan oleh responden 21, 18, 20, 4. Responden nomor 21 menunjukkan persentase sebesar 32,5\% rata-rata mendapatkan skor 1,3. Responden 18 menunjukkan porsentase $35 \%$ dengan rata-rata 1,4. Responden nomor 20 dan 4 menunjukkan persentase 37,5\% dengan ratarata 1,5. Secara keseluruhan capaian rata-rata aspek sikap siswa SMP Mathla'ul Anwar berjumlah $60,98 \%$ atau jumlah rata-rata 24,39 . 
Berdasarkan analisis data di atas 8 responden menunjukkan persentase kurang dari $50 \%$. Rata-rata dari indikator yang ditunjukkan menjawab 2 jawaban. Di antara soal yang mendapatkan 1 jawaban adalah indikator nomor 2, 5, 7, 8, dan 10. Angket yang dibagikan berkenaan dengan prilaku hormat dan patuh kepada orangtua, prilaku rendah hati, hemat, dan hidup sederhana.

Pembelajaran Pendidikan Agama Islam dan Budi Pekerti merupakan sebuah upaya untuk membentuk karakter peserta didik. Beberapa poin karakter yang diharapkan ada dalam diri peserta didik adalah sikap spiritual, disiplin, sopan santun, jujur, tanggung jawab dan percaya diri. ${ }^{12}$ Sejalan dengan itu, A. M. Wibowo menyatakan bahwa melalui pembelajaran PAI dapat menanamkan karakter-karakter yang diharapkan dengan baik. ${ }^{13}$ Sejalan penanaman nilai karakter pada peserta didik $87 \%$ berhasil menaikan nilai karakter peserta didik dan 13\% dengan pembelajaran PAI tidak adanya perubahan karakter pada peserta didik hal tersebut dipengaruhi oleh lingkungan dan kebiasaan keluarga yang kurang mendukung, sehingga sulitnya karakter peserta didik dirubah. ${ }^{14}$

Dengan demikian dapat disimpulkan bahwa karakter siswa yang masih kurang dari harapan merupakan sebagian kecil dari keberhasilan penanaman karakter pada mata pelajaran PAI. Dilihat dari hasil penelitian yang dilakukan oleh Fahmi \& Susanto. Tetapi sebagian besar bahwa pembelajaran PAI memiliki dampak yang besar terhadap perubahan karakter pada diri peserta didik.

2. Analisis butir soal aspek afektif di SMP Mathla'ul Anwar

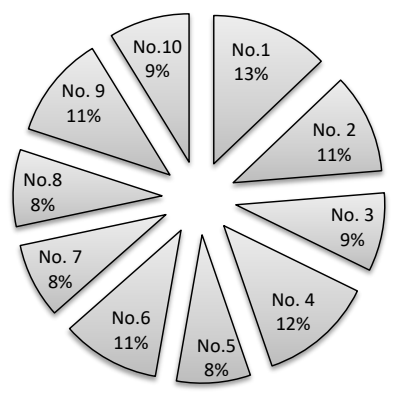

Gambar 2. Persentase Butir Soal Aspek Sikap di SMP Mathla'ul Anwar

\footnotetext{
${ }^{12}$ Fatimah \& Rusli Malli, "Implementasi Kurikulum 2013..."

${ }^{13}$ A. M. Wibowo, "Internalisasi Nilai-nilai Karakter Bangsa Melalui Mata Pelajaran PAI pada
} SMA Eks RSBI di Pekalongan," Analisa: Journal of Social Science and Religion, Vol. 21, No. 2 (2014): 291-303.

${ }^{14}$ Muhammad Nahdi Fahmi \& Sofyan Susanto, "Implementasi Pembiasaan Pendidikan Islam dalam Membentuk Karakter Religius Siswa Sekolah Dasar," PEDAGOGIA: Jurnal Pendidikan, Vol. 7 , No. 2 (2018): 85-89. 
Gambar 2 menunjukkan persentase pencapaian tiap indikator soal yang disebar di SMP Mathla'ul Anwar Margahayu. Berdasarkan hasil penghitungan setiap indikator soal didapatkan indikator dengan persentase tertinggi adalah nomor 1 menunjukkan pada persentase $13 \%$, indikator 4 menunjukkan $12 \%$, indikator 9, 2, 6 menunjukkan persentase $11 \%$, indikator 10 , dan 3 menunjukkan persentase $9 \%$, dan indikator 8,7 dan 5 menunjukkan persentase $8 \%$.

Pertama, mengenai karakter mematuhi perintah orangtua. Berdasarkan analisis di atas, pertanyaan pertama mengenai mematuhi perintah orangtua menunjukkan persentase terbesar, yaitu $13 \%$. Berdasarkan penyebaran soal didapatkan rata-rata peserta didik menjawab 4 jawaban, baik jawaban berbentuk positif maupun negatif. Di antara jawaban tersebut adalah langsung mengerjakannya, menuruti perintahnya tapi tidak langsung mengerjakannya dengan alasan sedang malas, menolaknya dengan alasan sedang mengerjakan hal lain seperti sedang belajar, kadang juga menolaknya langsung. Ada beberapa peserta didik yang memberikan jawaban langsung mematuhinya karena ia takut dimarahi orangtua. Hal tersebut berhubungan dengan pertanyaan kedua yaitu "alasan mereka mematuhi perintah orangtua" didapatkan jawaban mereka tau itu adalah bentuk berbakti kepada orangtua, tetapi sebagian juga menuliskan bahwa hal tersebut dilakukan karena takut bila tidak mau ia akan dimarahi, ada juga siswa yang menolak ketika diperintah oleh orangtua.

Secara umum bahwa pada usia kanak-kanak anak lebih patuh terhadap orangtua dibandingkan remaja. ${ }^{15}$ Karena ketika remaja mereka mulai berpikir bahwa perintah yang diberikan kurang rasional atau mereka berpresepsi sudah dewasa. Usia kanakkanak mereka hanya menerima setelah beranjak remaja mereka mulai sering berinteraksi dengan lingkungan agar mereka mengetahui gambaran lengkap tentang dirinya hal tersebut dapat berdampak pada anak mudah terpengaruh oleh lingkungan yang mana ia lebih sulit untuk diatur. ${ }^{16}$

Berdasarkan diskusi di atas dapat ditarik kesimpulan bahwa seorang remaja yang ketika menghadapai situasi harus mematuhi perintah orangtua ia akan langsung

\footnotetext{
${ }^{15}$ Emily S.Kuhn, Jenny Mai Phan, and Robert D. Laird, "Compliance with Parents' Rules: Between-Person and within-Person Predictions," Journal of Youth and Adolescence, Vol. 43, No. 2 (2014): 245-256.

${ }^{16}$ Winanti Siwi Respati, Aries Yulianto, dan Noryta Widiana, "Perbedaan Konsep Diri antara Remaja Akhir yang Mempersepsi Pola Asuh Orangtua Authoritarian, Permissive, dan Authoritative," Jurnal Psikologi, Vol. 4, No. 2 (2006): 119-138.
} 
mematuhinya tetapi juga ia dapat menolaknya dengan alasan-alasan lain. Hal tersebut, bisa terjadi karena pada usia remaja ia mulai lebih banyak berinteraksi dengan lingkungan sekitar yang membuatnya belajar tentang konsep diri yang berdampak pada pola pikir anak dalam mempertimbangkan perintah yang di berikan orangtua.

Kedua, mengenai hemat dan hidup sederhana. Sedangkan pertanyaan yang memiliki persentase terkecil adalah terdapat pada indikator nomor 5, 7 dan 8. Indikator nomor 5 siswa menuliskan keadaan harus menghormati orangtua. Indikator nomor 7 adalah tuliskan sikap yang kamu tunjukkan ketika melihat keran air yang menyala. Indikator nomor 8 adalah peserta didik dapat menuliskan sikap yang dapat diikuti berdasarkan cerita inspiratif yang dibacakan. Ketiga indikator diatas menunjukkan $8 \%$ dari keseluruhan jawaban yang diajukan.

Indikator nomor 7 dan 8 bersinggungan dengan prilaku hemat dan hidup sederhana. Karakter hemat penting dimiliki oleh peserta didik. Menurut Sapril, bahwa dengan dilaksanakannya pendidikan Islam adalah sebagai sebuah usaha internalisasi hidup sederhana. Terbukti bahwa dengan diterapkan pendidikan Islam dapat membentuk hidup sederhana seperti cara berpakaian, makan dan minum yang sederhana serta kepedulian sosial sesama pesera didik. ${ }^{17}$ Lebih lanjut al-Qur'an menyinggung tentang hidup sederhana "kelemahan akal itu bangga diri dan emosi, serta penyakit harta itu adalah pemborosan dan perampokan (Q.S. 7: 250).” Artinya bahwa hidup boros itu merupakan penyakit dan orang Islam haruslah hidup sederhana dan jangan berlebihlebihan. Hal tersebut harus dilakukan karena di akhira nanti semua harta yang kita miliki akan dipertanggung jawabkan untuk kegunaan kebaikan atau keburukan. ${ }^{18}$

Maka dapat disimpulkan bahwa indikator nomor 7 dan 8 menyinggung tentang sikap hemat dan hidup sederhana peserta didik belum dapat mengimplementasikan hal tersebut padahal dalam Islam manusia dianjurkan untuk hidup sederhana. Selain itu, salah satu tujuan untuk diterapkannya pendidikan agama Islam di sekolah diharapkan peserta didik dapat memiliki karakter hemat dan hidup sederhana.

\footnotetext{
${ }^{17}$ N. M. Sapril, "Aktualisasi Nilai-nilai Pendidikan Islam dalam Membentuk Pola Hidup Sederhana di Madin Al-Isnaini Montong Wasi," Palapa, Vol. 4, No. 1 (2016): 118-132.

${ }^{18}$ Muhammad Ashim bin Musthofa, "Nikmatnya Hidup Sederhana." https://almanhaj.or.id/3510-nikmatnya-hidup-sederhana.html (Diakses 30 Mei 2019).
} 
3. Profil Rata-Rata pencapaian tiap Indikator Soal

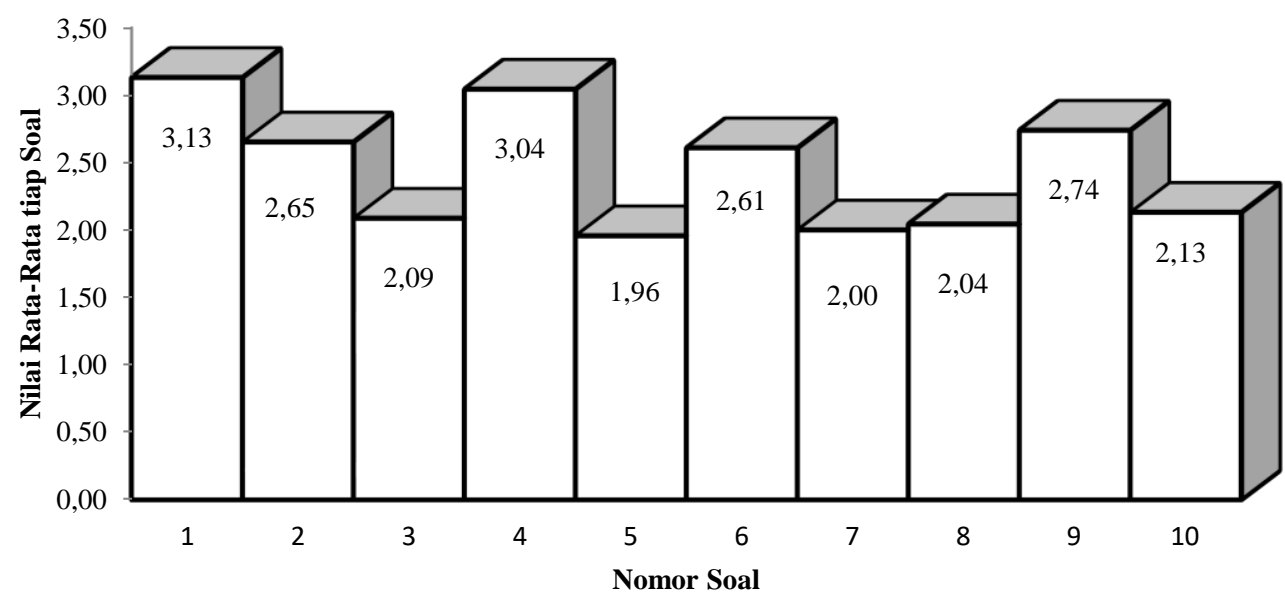

Gambar 3. Rata-Rata Tiap Indikator Soal

Gambar 3 menunjukkan rata-rata indikator soal yang disebar di SMP Mathla'ul Anwar Margahayu. berdasarkan hasil penghitungan didapatkan rata-rata keseluruhan 2,44 dengan rincian indikator nomor 1 menunjukkan rata-rata 3,13; indikator nomor 2 menunjukkan rata-rata 2,65; indikator nomor 3 menunjukkan rata-rata 2,09; indikator nomor 4 menunjukkan rata-rata 3,04; indikator nomor 5 menunjukkan rata-rata 1,96; Indikator nomor 6 menunjukkan rata-rata 2,6; indikator nomor 7 menunjukkan rata-rata 2,00; indikator nomor 8 menunjukkan rata-rata 2,04; indikator nomor 9 menunjukkan rata-rata 2,74; dan indikator nomor 10 menunjukkan rata-rata 2,13. Berdasarkan hasil penghitungan rata-rata dari 10 indikator rata-rata terendah ada di indikator nomor 5, yaitu 1,96 tentang keadaan apa saja kamu menghormati orangtua.

Sepuluh indikator yang disebar dapat dikelompokkan menjadi kelompokkelompok soal soal di antaranya:

Pertama, nomor 1 sampai 3 berindikator siswa menunjukkan sikap mematuhi orangtua, sesuai dengan Q.S. Al-Nisa: 36, sejalan dengan itu pertanyaan nomor 4 dan 5 memiliki indikator siswa menunjukkan hormat kepada orangtua, sesuai dengan Q.S. AlNisa: 36. Berdasarkan hasil seminar psikologi dan manusia salah satu faktor perkembangan remaja adalah pola asuh yang diterapkan di keluarga. Bahwa orangtua yang menggunakan pola asuh authoritarian lebih menekankan pada konformitas dan ketaatan mutlak, sehingga hal tersebut digunakan untuk membentuk kepatuhan pada anak, orangtua yang menggunakan pola asuh permisif para remaja cenderung 
menunjukkan sikap tidak kompeten dalam sosialisasi, tidak peka, lost control, sehingga timbul sikap yang agresif dan tidak patuh. ${ }^{19}$ Maka dapat disimpulkan bahwa peserta didik yang menunjukkan sikap menolak terhadap perintah orangtua bisa terjadi karena pola asuh orangtua yang kurang tepat. Sedangkan peserta didik yang menerima dan mematuhi perintah orangtua merupakan dampak positif dari pola asuh demokratif. Remaja yang mendapatkan pola asuh demokratis maka akan menunjukkan karakter yang kompeten, bahagia, bertanggungjawab, percaya diri, adaktif, kreatif mandiri, memiliki rasa ingin tahu yang besar, peka dan memiliki problem solving yang baik terhadap masalah yang dialami. ${ }^{20}$ Maka dapat disimpulkan bahwa untuk membentuk karakter hormat kepada orangtua disarankan menggunakan pola asuh demokratis.

Kedua, pertanyaan nomor 9 dan 10 memiliki indikator siswa dapat membangun cara-cara tersendiri untuk berprilaku rendah hati, hemat dan hidup sederhana sesuai dengan Q.S. Al-Furqan: 63 dan Q.S. Al-Isra: 27. Karakter cukup merupakan sikap yang harus dimiliki oleh anak karakter ini sama dengan sikap qana'ah. Qana'ah merupakan sikap merasa cukup. Pada hakikatnya qana'ah adalah meyakini sepenuhnya bahwa Allah memberikan apapun merupakan hal yang terbaik. ${ }^{21}$ Berkenaan dengan sikap hemat dan sederhana, hal tersebut sangat dianjurkan untuk seorang muslim karena itu merupakan salah satu sunnah Rasulullah. Beliau hidup sangat sederhana yang digambarkan tidur di atas tikar. Beliau mengumpamakan bagaikan berjalan di hari panas berhenti sejenak dan ditinggalkan. Islam merupakan agama yang berlandasakan nilai kesederhanaan yang tinggi sebagaimana yang dicontohkan Rasulullah sebagai suri tauladan. Sederhana merupakan sikap yang menjunjung tinggi kebijaksanaan dalam memenuhi kebutuhan hidup, tidak berlebih-lebihan, dan mencari materi. Jika ia dapat hidup sederhana, maka ia dapat memilih mana yang menjadi prioritas, baik perhatian, tenaga maupun harta. ${ }^{22}$ Dapat disimpulkan bahwa cara berprilaku rendah hati, hemat dan hidup sederhana adalah dengan meniru Rasulullah sebagai suri tauladan bagi umat Islam dan haruslah bersikap positive thinking terhadap apapun ketetapan yang allah berikan karena itu semua merupakan hal yang terbaik bagi manusia.

\footnotetext{
${ }^{19}$ Yuli A. Rozali, "Kecerdasan Interpersonal Remaja..."

${ }^{20}$ Ibid.

${ }^{21}$ Amirulloh Syarbini dan Heri Gunawan, Mencetak Anak Hebat (Jakarta: Elex Media Komputindo, 2014), 146.

${ }^{22}$ Yusuf Assidiq, "Hidup Sederhana ala Rasulullah," https://www.republika.co.id/berita/duniaIslam/Islam-nusantara/17/11/17/ozkb54313-hidup-sederhana-ala-rasulullah (Diakses 31 Mei 2019).
} 
Icmiati Santika, Chaerul Rohman, Dindin Jamaluddin: Analisis Ketercapaian Sikap di SMP Mathla'ul Anwar Margahayu

\section{Simpulan}

Berdasarkan analisis sikap yang dilakukan di SMP Mathla'ul Anwar secara keseluruhan peserta didik menunjukkan persentase $61 \%$. Dengan rincian kelompok tinggi antara 100-70\% ada 6 responden, kelompok sedang antara 51-69\% ada 10 responden dan kelompok rendah antara 0-50\% ada 7 responden. Sedangkan berdasarkan analisis per indikator soal menunjukkan rata-rata nilai tertinggi pada indikator nomor 1 dengan rata-rata 3,1 dan rata-rata nilai terendah pada nomor 5, 7 dan 8 yaitu 2,0. Untuk memaksimalkan beberapa indikator yang kurang maka dibuat solusi penanaman sikap rendah hati, hemat dan hidup sederhana dengan mengingat akan pentingnya sikap tersebut dengan penerapak pola asuh yang tepat bagi anak.

\section{E. Daftar Pustaka}

Departemen Pendidikan Nasional. Undang-Undang Nomor 20 Tahun 2003 Tentang Sistem Pendidikan Nasional. Jakarta: Depdiknas, 2003.

Dirgantara, Hikma. "4 Jenis Pola Asuh untuk Mendidik Anak." https://www.finansialku.com. Diakses 29 Mei 2019.

Fahmi, Muhammad Nahdi \& Sofyan Susanto. "Implementasi Pembiasaan Pendidikan Islam dalam Membentuk Karakter Religius Siswa Sekolah Dasar." PEDAGOGIA: Jurnal Pendidikan, Vol. 7, No. 2 (2018): 85-89.

Fatimah \& Rusli Malli. "Implementasi Kurikulum 2013 terhadap Sikap Peserta Didik dalam Pembelajaran Pendidikan Agama Islam." TARBAWI: JURNAL PENDIDIKAN AGAMA ISLAM, Vol. 2, No. 1 (2017): 91-99.

Jamaludin, Acep Komarudin \& Koko Khoerudin. Pembelajaran Perspektif Islam. Bandung: Remaja Rosdakarya, 2015.

Kuhn, Emily S., Jenny Mai Phan, and Robert D. Laird. "Compliance with Parents' Rules: Between-Person and within-Person Predictions." Journal of Youth and Adolescence, Vol. 43, No. 2 (2014): 245-256.

Musthofa, Muhammad Ashim bin, "Nikmatnya Hidup Sederhana." https://almanhaj.or.id/3510-nikmatnya-hidup-sederhana.html (Diakses 30 Mei 2019).

Pratiwi, Firda, et. al. "Pendidikan Anak Menurut Zakiah Darajat," POTENSIA: Jurnal Kependidikan Islam, Vol. 4, No. 1 (2018): 46-62.

Putri, E. I. E. \& I. G. A. A. Noviekayati. "Religiusitas, Pola Asuh Otoriter dan Perilaku Prososial Remaja di Pondok Pesantren." Persona: Jurnal Psikologi Indonesia, Vol. 4, No. 3 (2015).

Rahayu, S. \& F. Hendrati. "Pola Asuh Demokratis dan Kecerdasan Emosional dengan Prestasi Belajar Siswa-Siswi SMP Bilingual." Persona: Jurnal Psikologi Indonesia, Vol. 4, No. 3 (2015). 
Respati, Winanti Siwi, Aries Yulianto, dan Noryta Widiana. "Perbedaan Konsep Diri antara Remaja Akhir yang Mempersepsi Pola Asuh Orangtua Authoritarian, Permissive, dan Authoritative." Jurnal Psikologi, Vol. 4, No. 2 (2006): 119-138.

Rozali, Yuli A. "Kecerdasan Interpersonal Remaja Ditinjau dari Penerapan Pola Asuh Orangtua. In Seminar Psikologi \& Kemanusiaan (pp. 446-452).

Sapril, N. M. "Aktualisasi Nilai-nilai Pendidikan Islam dalam Membentuk Pola Hidup Sederhana di Madin Al-Isnaini Montong Wasi." Palapa, Vol. 4, No. 1 (2016): 118-132.

Syah, Muhibbin. Psikologi Pendidikan dengan Pendekatan Baru. Bandung: Remaja Rosdakarya, 2013

Syarbini, Amirulloh dan Heri Gunawan. Mencetak Anak Hebat. Jakarta: Elex Media Komputindo, 2014 Assidiq, Yusuf. "Hidup Sederhana ala Rasulullah." https://www.republika.co.id/berita/dunia-Islam/Islamnusantara/17/11/17/ozkb54313-hidup-sederhana-ala-rasulullah (Diakses 31 Mei 2019).

Wibowo, A. M. "Internalisasi Nilai-nilai Karakter Bangsa Melalui Mata Pelajaran PAI pada SMA Eks RSBI di Pekalongan." Analisa: Journal of Social Science and Religion, Vol. 21, No. 2 (2014): 291-303. 